\title{
Distribution of Stimulants Etefon and Fertilization for Latex Plant Rubber
}

\author{
Anis Tatik Maryani ${ }^{1 *}$, Sosiawan Nusifera ${ }^{1}$, Norton Matondang ${ }^{1}$ and Yudha Gusti Wibowo ${ }^{2}$ \\ ${ }^{1}$ Faculty of Agriculture, Jambi University, Indonesia. \\ 2 Postgraduate Student, Jambi University, Indonesia. \\ *Corresponding author email id: anis_tatik@yahoo.com \\ Date of publication (dd/mm/yyyy): 05/05/2019
}

\begin{abstract}
The study aims to determine the effect of stimulants etefon and dose of fertilizer to the results of latex rubber tree (Hevea brasiliensis Muell. Arg) clone PB 260. This study was conducted this study was conducted in a community garden located on Jl. Tri Brata Km 14. Village cottage Desk, District Mestong, Muaro Jambi, Jambi Province. This study uses the design field by placing a treatment randomized into the experimental unit, there were 9 treatments in this study is $\mathrm{P} 1=$ etefon $2.0 \%$ + fertilizer $152 \mathrm{~g}, \mathrm{P} 2=$ etefon $2.0 \%$ + FERTILIZER $220 \mathrm{~g}$, P3 = etefon $2.0 \%$ + fertilizer $302 \mathrm{~g}, \mathrm{P} 4=$ etefon $2.5 \%$ + fertilizer $152 \mathrm{~g}, \mathrm{P5}=$ etefon $2.5 \%+$ fertilizer $220 \mathrm{~g}, \mathrm{P6}=$ etefon $2.5 \%+$ fertilizer $302 \mathrm{~g}, \mathrm{P} 7$ = etefon 3, $0 \%$ + fertilizer $152 \mathrm{~g}, \mathrm{P8}=$ etefon $3.0 \%+$ pupuk220 g, P9 = etefon $3.0 \%+302 \mathrm{~g}$ fertilizer. The observed variables include latex weight, volume latex and dry rubber content (KKK) processed. The results showed that administration intraksi etefon and fertilizer showed the results of latex. Giving etefon 3.0\% + pupuk152 $\mathrm{g}$, etefon $3,0 \%+220 \mathrm{~g}$ fertilizer, fertilizer etefon $3.0 \%+302 \mathrm{~g}$ of weight showed the highest latex and latex volume dibandingankan with other treatments, but inversely proportional to the dry rubber content (KKK) processed. Dry rubber content (KKK) processed etefon best shown by the treatment of $2.0 \%+220 \mathrm{~g}$ fertilizer. Giving etefon shows a real influence on the outcome of latex, while fertilizer showed no effect on the outcome of latex.
\end{abstract}

Keywords - Rubber, clones PB 260, Latex, rubber stimulants, Etefon and Fertilization Rubber.

\section{INTRODUCTION}

Rubber plantations have an important role for the economy of the State of Indonesia, where the rubber plantation area in Indonesia reached 3.6 million hectares, and placed Indonesia as the country has a total area of rubber plantations world beat Thailand and Malaysia [1].

Although Indonesia has the largest rubber plantation in the world but Indoneisa only ranked second as the country's natural rubber production and still lags behind countries Thailand who coined the smaller acreage than Indonesia [2].

Rubber plant as a producer of natural rubber is a commodity that is very important for Indonesia as a foreign exchange earner and provide jobs for the community. Directorate general of record export value of rubber plantations in 2013 reached 2.7 million tons with a sales value reached 6.9 billion US dollars, then in 2014 reached 2.62 million tons with a sales value of 4.7 billion US dollars. In 2015, noted that the rubber plantation area in Indonesia has reached 3.6 million hectares of which $85 \%$ is public rubber, $9 \%$ and $6 \%$ of private rubber rubbery state, with productivity in 2015 reached $1,036 \mathrm{~kg} / \mathrm{ha} / \mathrm{yr}$ is still low tegolong compared with the State Thailand which reached 1,600 kg /ha /yr [1]. Rubber plant plays an important role for the province of Jambi, Jambi major region has a rubber plantation area of 3.6 million hectares with a productivity of $867 \mathrm{~kg} / \mathrm{ha} / \mathrm{yr}$ is still relatively (Table 1). 
Table 1. Area, Production and Productivity of the National Rubber Year 2012-2016.

\begin{tabular}{cccc}
\hline Year & Total Area (ha) & Production (tons) & Productivity (kg / ha) \\
\hline 2012 & 3506201 & 3012254 & 859.12 \\
2013 & 3555946 & 3237433 & 910.44 \\
2014 & 3606245 & 3153186 & 874.36 \\
2015 & 3621102 & 3145398 & 868.63 \\
2016 & 3639092 & 3.15778 million & 867.73 \\
\hline Source: $[1]$
\end{tabular}

The increase in rubber production should be coupled with a focus on the health of the rubber plant. Healthy plants will produce a stable latex productivity. Increasing crop production, it will also increase the loss of nutrients in the soil. The amount of nutrients transported together harvest in $1000 \mathrm{~kg}$ of dry rubber is equivalent to $20.4 \mathrm{~kg}$ of urea, $6.4 \mathrm{~kg}$ of SP-36, $13.8 \mathrm{~kg}$ and $6.3 \mathrm{~kg} \mathrm{~K}$ Kieserit. While the addition of nutrients that occur naturally in the soil the process is very slow and the amount is very small. Fertilization is the most important thing at this time, because the rubber plantations at this time tends to use superior clones that high productivity. The high productivity of latex related to nutrients being consumed, to compensate for the high productive it is necessary to increase the nutrient is through fertilization. If fertilization does not do, it is feared will reduce the productivity of rubber and also will cause a decrease in soil fertility in the future. The use of stimulants has been done over the last two decades. The use of stimulant aims to increase the flow of latex and extend the latex. Stimulants are a mixture of vegetable oils (eg palm oil) and hormone ethylene or other active ingredients. Generally, the use of stimulants is done on rubber that has aged adult with the aim to increase latex yield in order to obtain additional benefits for farmers [3].

Etefon as an active ingredient in the stimulant comprised of compounds 2-chlorortylposphonic acid, which serves to increase the production of endogenous ethylene in the rubber plant [4]. Ethylene contained in the stimulus is a major factor in the rise in rubber latex production plant. Enzymes involved in the biosynthesis of ethylene is one of them is aminosiklopopana-1- carboxylic acid oxidase ACO. ACO is a catalyst in the change aminoksiklopopana-1- carboxylic acid into ethylene [5].

The use of stimulants on rubber does not always give the expected response, this matter depends on each clone and it is good use of stimulants applied to the rubber plant that has been aged 10 years to 15 years. Excessive use of stimulants can lead to deviations metabolic processes, namely, thickening bark, necrosis, the formation of cracks in the skin and the appearance of parts that are not productive. The use of stimulants can cause inhibition latex flow caused by coagulation of particles known as dry tapping grooves [6].

Give states that stimulant in Clones IRR 39 is proven to boost production by $164 \%-181 \%$ compared to without the use of stimulants. Research carried out for 7 years showed that treatment tapping system 1/2s (oblique slices along the half spiral or girth) $\mathrm{d} 3$ (tapped 3 days) or better known as $1 / 2$ s Etefon $\mathrm{d} 3+2.5 \%$, giving a higher yield compared to other treatments right [7].

Regular fertilization on crop yield (TM) gum can increase productivity by $15-25 \%$ [8]. Administration of a single fertilizer increases the production of compound fertilizers $9 \%$ while increasing production $11 \%$ compared with no fertilization [9]. 


\section{RESEARCH METHODS}

This study was conducted in a community garden located on Jl. Tri Brata Km 14. Village cottage Desk, District Mestong, Muaro Jambi, Indonesia. This study has conducted during 2 months from the date of 5 September to 5 November 2017.

This experiment was conducted in a rubber plantation located in the village folk cottage Desk Mestong Subdistrict, Regency of Muara Jambi, Jambi Province. The experimental garden menggukan spacing of $3 \mathrm{mx} 6$ $\mathrm{m}$, without plant-stream. This trial design receipts field in conjunction with treatment randomized into the experimental unit. The treatment given to the rubber plant and the GCC have been assumed to be uniform by size girth, canopy condition, age of the plant and field conditions tapping. The treatments were the results of latex rubber tree (Hevea brasiliensis) Clones PB260 is as follows:

P1: Etefon 2.0\% + $152 \mathrm{~g}$ fertilizer (Urea $58.3 \mathrm{~g}$, SP $3643.3 \mathrm{~g}$ and $50 \mathrm{~g} \mathrm{KCL}$ ).

P2: Etefon 2.0\% + fertilizer 220 g (79,7 g Urea, SP and KCL 3664.9 g 75 g).

P3: Etefon 2.0\% + fertilizer 302 g (115.6 g Urea, SP $3686.6 \mathrm{~g}$ and KCL $100 \mathrm{~g}$ ).

Q4: 2.5\% + pupuk152 Etefon g (58.3 g Urea, SP and KCL $3643.3 \mathrm{~g} 50 \mathrm{~g})$.

P5: Etefon 2.5\% +fertilizer220 g (79,7 g Urea, SP and KCL 3664.9 g 75 g).

P6: Etefon 2.5\% +fertilizer 302 g (115.6 g Urea, SP $3686.6 \mathrm{~g}$ and KCL $100 \mathrm{~g}$ ).

P7: Etefon 3.0\% +fertilizer152 g (58.3 g Urea, SP and KCL $3643.3 \mathrm{~g} 50 \mathrm{~g})$.

Q8: Etefon 3.0\% +fertilizer 220 g (79,7 g Urea, SP and KCL 3664.9 g 75 g).

Q9: Etefon 3.0\% +fertilizer302 g (115.6 g Urea, SP $3686.6 \mathrm{~g}$ and KCL $100 \mathrm{~g})$. Each treatment repeated 5 times, so that the plant tested sample as many as 45 plants.

Observation variables include the volume of latex is obtained by measuring the volume of liquid latex on the measuring cup. Data Pegambilan implemented after the flow stops tapping latex in the field with a time of \pm 3 hours after tapping. Heavy latex all the samples were weighed using scales. Data is collected after the flow stops latex tapping grooves to within \pm 3 hours after tapping. Measurement KKK dialakukan processed each finished tapping. Production weighed as latex and lump. KKK processed measured using the gravimetric method, based on comparisons \% dry weight and wet weight of 5 grams latex. Drying is done to use your oven at a temperature of $1000 \mathrm{C}$ until the weight remains. The formula used to measure the KKK processed are as follows:

$$
\% K K K=\frac{\text { dryweight }}{\text { grossweight }} \times 100
$$

To see the effect of the treatment of the observed variables do several stages of data analysis. First, test data normality using the Kolmogorov-Smirnov test for normality, variance homogeneity test is then performed using Bartlett's test. Once the data is tested normal and homogeneous then do Anova and to a further test by Duncan test.

\section{RESULTS AND DISCUSSION}

Heavy Latex

Copyright (C) 2019 IJRAS, All right reserved 
Based on the results of statistical analysis, and pempukan etefon combination treatment showed a real influence on the average weight of latex. The average weight of the rubber plant latex clone PB 260 in treatment can be seen in Table 3.

Table 3. Average Weight Latex in Treatment Provision Etefon and Fertilization Stimulant

\begin{tabular}{cc}
\hline Treatment & Latex Weight (g) \\
\hline Etefon $2.0 \%+$ Fertilizer $152 \mathrm{~g}$ & $179.00 \mathrm{a}$ \\
\hline Etefon $2.0 \%+$ Fertilizer $220 \mathrm{~g}$ & $230.66 \mathrm{ab}$ \\
Etefon $2.0 \%+$ Fertilizer $302 \mathrm{~g}$ & $174.44 \mathrm{a}$ \\
Etefon $2.5 \%+$ Fertilizer $152 \mathrm{~g}$ & $201.66 \mathrm{a}$ \\
Etefon $2.5 \%+$ Fertilizer $220 \mathrm{~g}$ & $241.88 \mathrm{ab}$ \\
Etefon $2.5 \%+$ Fertilizer $302 \mathrm{~g}$ & $301.00 \mathrm{bc}$ \\
Etefon $3.0 \%+$ Fertilizer $152 \mathrm{~g}$ & $344.55 \mathrm{c}$ \\
Etefon $3.0 \%+$ Fertilizer $220 \mathrm{~g}$ & $352.44 \mathrm{c}$
\end{tabular}

Based on the table, the average weight of the lowest latex indicated by treatment etefon $2.0 \%+$ fertilizer $220 \mathrm{~g}$ with an average weight of latex $173.11 \mathrm{~g}$ and was not significantly different to the treatment etefon $2.0 \%+$ fertilizer $152 \mathrm{~g}$, etefon $2,0 \%$ + fertilizer $302 \mathrm{~g}$, etefon $2.5 \%+$ fertilizer $152 \mathrm{~g}$, etefon $2.5 \%+220 \mathrm{~g}$ fertilizer and manure etefon $2.5 \%+302 \mathrm{~g}$. The average weight of the highest latex indicated in the treatment etefon $3.0 \%+$ fertilizer $302 \mathrm{~g}$ with an average weight of latex $352.44 \mathrm{~g}$ and was not significantly different to the treatment etefon $3.0 \%$ + fertilizer $152 \mathrm{~g}$ with an average $301 \mathrm{~g}$ and etefon $3.0 \%$ + fertilizer $220 \mathrm{~g}$ with an average $344.55 \mathrm{~g}$.

The average yield above shows that the treatment Etefon $3.0 \%+302 \mathrm{~g}$ fertilizer and manure Etefon $3.0 \%+$ $220 \mathrm{~g}$ giving a higher weight allegedly with increasing doses of $3 \%$ etefon be able to increase the weight of the latex. This is in accordance with the opinion Boerhendhy (2013), which states that the use of etefon can significantly increase latex yield in accordance with the etefon concentration. Increased fertilizer dosage did not show any significant changes to latex yield Fertilization allegedly given in this study aims to maintain the availability of nutrients for the plants because of the availability of nutrients in the soil but have not been able to influence the excretion of latex it, which states in an effort to optimize the productivity of latex [10]

Treatment etefon $2.0 \%+152 \mathrm{~g}$ fertilizer, fertilizer etefon $2.0 \%+220 \mathrm{~g}$, etefon $2.0 \%+$ pupuk302 g, etefon $2.5 \%+152 \mathrm{~g}$ fertilizer, fertilizer etefon $2.5 \%+220 \mathrm{~g}$ and etefon $2.5 \%+$ fertilizer $302 \mathrm{~g}$ less than the maximum shows the results compared with other treatments, it is suspected because etefon lower concentration and is unable utuk significantly increase the weight latex adntara etefon dose $2 \%$ and $2.5 \%$. Concentration etefon stimulant heavily influence the latex as a stimulant has a function to maintain a longer latex drainage and more, so that the latex obtained more than without the use stimulanetefon [11].

Latex weight was highest in the first tapping after basting etefon three days previously. In the next tapping latex tends to show weight, it is suspected basting etefon only able to penetrate $1 \mathrm{~cm}$ and the less influence etefon the next tapping availability etefon getting smaller compared to the first tapping. 


\section{Volume Latex}

Based on the results of statistical analysis, and fertilizer etefon combination treatment showed a real influence on the average volume of latex. The average volume of latex rubber tree clones PB 260 in treatment can be seen in Table.

Table. The average volume of Latex in Treatment Provision Etefon and Fertilization Stimulant.

\begin{tabular}{cc}
\hline Treatment & Latex volume (ml) \\
\hline Etefon $2.0 \%+$ fertilizer $152 \mathrm{~g}$ & $156.55 \mathrm{a}$ \\
Etefon $2.0 \%+$ fertilizer $220 \mathrm{~g}$ & $137.88 \mathrm{a}$ \\
Etefon $2.0 \%+$ pupuk $302 \mathrm{~g}$ & $193.00 \mathrm{ab}$ \\
Etefon $2.5 \%+$ fertilizer $152 \mathrm{~g}$ & $140.44 \mathrm{a}$ \\
Etefon $2.5 \%+$ fertilizer $220 \mathrm{~g}$ & $152.66 \mathrm{a}$ \\
Etefon $2.5 \%+$ pupuk $302 \mathrm{~g}$ & $203.22 \mathrm{ab}$ \\
Etefon $3.0 \%+$ fertilizer $152 \mathrm{~g}$ & $258.66 \mathrm{bc}$ \\
Etefon $3.0 \%+$ fertilizer $220 \mathrm{~g}$ & $297.33 \mathrm{c}$ \\
Etefon $3.0 \%+$ fertilizer $302 \mathrm{~g}$ & $302.11 \mathrm{c}$
\end{tabular}

Based on the table, the average weight of the lowest latex indicated by treatment etefon $2.0 \%+$ fertilizer $220 \mathrm{~g}$ with an average weight of latex $137.88 \mathrm{ml}$ which was not significantly different to the treatment etefon $2.0 \%+$ fertilizer $152 \mathrm{~g}$, etefon $2.0 \%$ + fertilizer $302 \mathrm{~g}$, etefon $2.5 \%$ + fertilizer $152 \mathrm{~g}$, etefon $2.5 \%$ + fertilizer220 g and etefon $2.5 \%+$ fertilizer $302 \mathrm{~g}$. The average volume of latex ditunjunkan highest in treatment etefon $3.0 \%$ +fertilizer $302 \mathrm{~g}$ with an average weight of latex $302.11 \mathrm{ml}$ were not significantly different to the treatment etefon $3.0 \%+$ fertilizer $152 \mathrm{~g}$ with an average $301 \mathrm{ml}$ and etefon $3.0 \%$ + fertilizer $220 \mathrm{~g}$ with an average $344.55 \mathrm{ml}$.

The average yield above shows that the treatment etefon $3.0 \%+$ fertilizer $152 \mathrm{~g}$, etefon $3.0 \%+$ fertilizer $302 \mathrm{~g}$ and etefon $3.0 \%+$ fertilizer $220 \mathrm{~g}$ giving a higher volume, allegedly with etefon concentration of $3 \%$ which is the highest concentration in the treatment of this case in accordance with the opinion of Khairi et al (2015) which states that the enhanced provision of etefon then also increase the flow of latex reinforced with the opinions Siregar and Suhenry (2013) which states that the use of etefon able to extend the time of jetting latex through cell physiology to maintain turgor pressure remains high so that production is obtained (in units of volume) than without given etefon.

The length of the latex flow affects the outcome of latex, old latex flow is influenced by the ethylene gas. Giving etefon on the plant triggers the formation of ethylene, wherein the ethylene on the network can stabilize the latex vessels lutoid which is a fraction of a latex base that contains cations. Lutoid stabilizing role is very important because if lutoid burst, cations will react with the rubber particles are negatively charged, causing coagulation. Causing the latex coagulation process stops dripping. Therefore, any use of stimulants tuk goal is to delay clotting so that the latex vessels longer period of latex flow (Siregar et al., 2013).

Effect of fertilizer application in the treatment showed no significant differences when viewed based dose of fertilizer treatment is given, one of the factors that led to the sausage fertilizer did not significantly affect the vo- 
-lume of latex due to the nature of the fertilizer that is systemic in the plant.

Volume latex is roughly equal to the weight garafik latex latex where the peak volume is highest in the first tapping after three days previously done basting etefon. From the graph shows a decline occurs continuously after first tapping is done, this is because the content of etefon the latex vessels that permeate into the latex vessels has decreased, causing the difference in volume between the first tapping and so to the extent the content of a given etefon absorbed.

\section{Dry Rubber Content (KKK) Prepared}

Based on the results of statistical analysis (Appendix 9), and puemupukan etefon combination treatment showed a real influence on the average KKK processed latex. On average KKK olahan latex rubber tree clones PB 260 in treatment can be seen in Table.

Table 4. The average dry rubber content (KKK) Processed Latex Stimulant in Provision Treatment Etefon and Fertilization.

\begin{tabular}{|c|c|}
\hline Treatment & Dry rubber content (\%) \\
\hline Etefon $2.0 \%+$ Fertilizer $152 \mathrm{~g}$ & $47.64 \mathrm{bc}$ \\
\hline Etefon $2.0 \%+$ Fertilizer $220 \mathrm{~g}$ & $48.67 \mathrm{c}$ \\
\hline Etefon $2.0 \%+$ Fertilizer $302 \mathrm{~g}$ & $47.31 \mathrm{~b}$ \\
\hline Etefon $2.5 \%+$ Fertilizer $152 \mathrm{~g}$ & $47.64 \mathrm{bc}$ \\
\hline Etefon $2.5 \%+$ Fertilizer $220 \mathrm{~g}$ & $47.24 \mathrm{~b}$ \\
\hline Etefon $2.5 \%+$ Fertilizer $302 \mathrm{~g}$ & $46.68 \mathrm{~b}$ \\
\hline Etefon $3.0 \%+$ Fertilizer $152 \mathrm{~g}$ & $45.44 \mathrm{a}$ \\
\hline Etefon $3.0 \%+$ Fertilizer $220 \mathrm{~g}$ & $45.48 \mathrm{a}$ \\
\hline Etefon $3.0 \%+$ Pupuk302 g & $45.55 \mathrm{a}$ \\
\hline
\end{tabular}

Highest processed KKK indicated in the treatment Etefon $2.0 \%+$ fertilizer $220 \mathrm{~g}$ with an average of $48.67 \%$, further treatment Etefon $2.0 \%$ + fertilizer $152 \mathrm{~g}$ with an average of $47.64 \%$, which differ not Etefon significant effect on the treatment of $2.5 \%$ + fertilizer $152 \mathrm{~g}$ with an average of $47.64 \%$ subsequent treatment Etefon $2.0 \%+$ fertilizer $302 \mathrm{~g}$ with an average of $47.31 \%$ which is not significant to the treatment Etefon $2.5 \%+$ fertilizer $220 \mathrm{~g}$ with an average of $47.25 \%$ and treatment Etefon $2.5 \%$ + fertilizer $302 \mathrm{~g}$ with an average of $46.69 \%$. KKK lowest processed by the treatment shown Etefon $3.0 \%+$ fertilizer $152 \mathrm{~g}$ with an average of $45.4 \%$, which is not significantly different from the treatment Etefon 3.0\% + fertilizer $220 \mathrm{~g}$ with an average of $45.49 \%$ and treatment Etefon $3,0 \%+$ fertilizer $302 \mathrm{~g}$ with an average of $45.56 \%$.

From the table, showed that the treatment Etefon $2.0 \%+220 \mathrm{~g}$ cendung fertilizer has a higher KKKolahan, it is presumably because the treatment Etefon $2.0 \%+220 \mathrm{~g}$ fertilizer is treatment using stimulants to its lowest Etefon etefon $2 \%, \mathrm{p}$ this is in accordance with the opinion of Khairil [12] which states that the dose effect terhadapat KKK etefon processed and inversely proportional to the concentration etefon KKK treated.

KKK preparations are measurable parameters that show comparisons percent rubber amount compared to the amount of water in the latex, the rubber content in the latex steeper, the lower the water content of the latex and 
vice versa [13]. The observation of the overall KKKolahan seen that the range of percent KKKolahan is at $45.44 \%$ to $48.67 \%$, and states that the use of etefon then KKKolahan generally declined. However the decline KKK processed in this study quite good for not less than $30 \%$ as standard KKK processed by administering stimulants. KKK processed garafik inversely proportional to the weight of latex and latex volume. In the graph above shows the decline occurred in the first tapping after basting etefon three days previously. In the next tapping KKKolahan tends to rise [14].

\section{CONCLUSIONS AND RECOMMENDATIONS}

\section{Conclusion}

Based on the results of research on Effect of Stimulants Etefon and fertilization on the Result Latex Rubber Plant (Hevea brasiliensis) clones PB 260 can be concluded that:

1. Etefon concentration and dose combinations of fertilizer significantly affected the observation variables.

2. Etefon concentration of $3 \%$ by weight and volume showed the best latex than the concentration etefon etefon $2 \%$ and $2.5 \%$.

\section{Suggestion}

Further studies should be done to the concentration etefon given the highest concentration of these studies show the best results, as well as to the dose of fertilizer to conduct further research see the effect of fertilization in this study is less significant.

\section{REFERENCE}

[1] Directorate General of Plantation. Indonesian Rubber Plantation in 2016. Statistics from 2014 to 2016. Jakarta

[2] Budiman H. 2012. The Superior Rubber cultivation. New Library Press. Yogyakarta.

[3] Setyamidjaja, D. 1993. Rubber Cultivation and Pengolahan.Kanisus. Yogyakarta

[4] Sumarmadji, Karyudi, and THS Siregar. 2005. Recommendations

[5] Sinamo, H., Charloq., Rosmayati, and Radite. Latex Production 2015.Respon in Different Time Application at Some of Giving Clones Rubber Plant Hormone Ethylene Various Sources. Faculty of Agriculture, North Sumatera. Online Journal Agroekoteaknologi .ISSN No. 2337-6597.

[6] Tistama, R., and THS Siregar. 2005. Development of Research Stimulants for Streaming Latex (Hevea brasiliensis) .Warta perkaretan

[7] Boerhandhy I. Tapping 2013.Penggunaan Stimulants Early To Increase Production Research Institute 39. The clones IRR Sembawa. Rubber Research Journal. 31 (2): 117-126.

[8] Nunggroho, PA, Istianto. 2009. Importance of Fertilization Rubber Plant. LPPcom White River Research Institute

[9] Andrijanto, A., Karno, and Legowo, A,M. 2015. Effect of Fertilizer on Production Type Latex Rubber Plant in Business Aspects of Income and Profit Oriented Full Sadap Tlogo Plantation. Diponegoro. Vol University. 33, No. 1

[10] Boerhendhy, I. and K. Amypalupy. 2010. Optimizing Productivity through Rubber Planting Material Usage, Maintenance, Exploitation and Rejuvenation System Plant. Sembawa Research Institute. Banyu Asin

[11] Siregar, THS, Junaidi and Atminingsih. 2013. Alternatifpenggunaan stimulant ethylene gas in production optimization. Paper training workshop rubber plant exploitation towards higher productivity and optimal economic lives. Medan, 18 to 21 March. Sungei Putih Research, Terrain.

[12] Khairil Fahmi, Sampoerno, M. Amrul Khoiri. 2015. JOM Faperta Vol. 2 No. October 2nd, 2015 Provision of stimulants Etefon with Groove Application Techniques in Crop Production Latex Rubber (Hevea brasiliensisMuell Arg.). Agroeco technology, Faculty of Agriculture, University of Riau.

[13] Elly, N. 2006. Influence of the development of the depolimerasi latex rubber particles with oxidation reduction reaction. Essay. Bogor: Faculty of Agricultural Technology, Bogor Agricultural University

[14] Siregar, THS and I. Suhendry. 2013. Aquaculture and Rubber Technology. Doubleday. Bogor. Sower Swadaya, Jakarta.

\section{AUTHOR's ProfiLe}

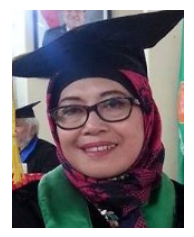

Prof. Dr. Hj. Anis Tatik Maryani is a Professor in Jambi University. She has completed study in Jambi University, Andalas University and Bogor Agriculture Institute, Indonesia. Prof. Anis has been dean of a postgraduate program in Jambi University, Indonesia. 
Sosiawan Nosifera is a lecturer in Agriculture Department in Universitas Jambi, Indonesia.

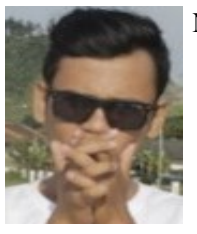

Norton Martondang is a student in Agriculture Department in Universitas Jambi, Indonesia.

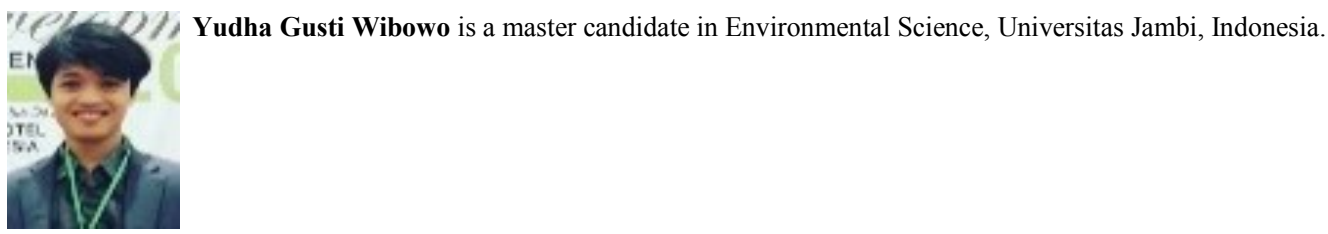

